\title{
The relationships among leadership styles, communication skills, and employee satisfaction: A study on equal employment opportunity in leadership
}

\author{
Tri Wikaningrum \\ Diponegoro University/ Universitas Islam Sultan Agung, Indonesia \\ Udin \\ Ahyar Yuniawan \\ Diponegoro University, Indonesia
}

\section{Keywords}

Leadership styles, communication skills, employee satisfaction, equal employment opportunity

\begin{abstract}
This study attempted to analyze the relationships among leadership styles, communication skills, and employee satisfaction. This study also examined the potential of women in leadership to support the practice of equal employment opportunities from gender side in organization. Data were collected from 200 selfadministered survey using questionnaires completed by employees at private Islamic universities in Semarang city, Indonesia. Regression analysis was used to test the hypotheses. The results showed that leadership styles and communication skills have a significant effect on employee satisfaction. However, based on employees' perceptions, this study revealed no significant difference between leadership styles and communication skills of male and female leaders.
\end{abstract}

Corresponding author: Udin

Email address for corresponding author: udin_labuan@yahoo.com

First submission received: $7^{\text {th }}$ November 2017

Revised submission received: 22 ${ }^{\text {nd }}$ January 2018

Accepted: $5^{\text {th }}$ March 2018

\section{Introduction}

There are many expert opinions on the importance of communication in leadership. According to Holladay and Coombs (1993), leadership is a behavior carried out by communication, in which communication clarifies perceptions of a leader's charisma. This is clarified by Hall \& Lord's idea (1995), saying that the leader message conveys affective and cognitive strategies. When the leader effectively communicates his/her vision, he/she is more likely to gain the employees' trust, which eventually affects communicating satisfaction between the leader and the followers (Madlock, 2008).

Shaw (2005) stressed that in order to be perceived as competent communicators, leaders must share and respond to information on time, pay attention to others' points of view, communicate clearly and concisely to all levels of organization, and use all existing communication channels and various communicative resources such as language, gestures, and sounds. Communication skills also play an important role in influencing attitudes, such as employees' satisfaction. It is not only about satisfaction in terms of communication with leaders, but also satisfaction with their jobs. Effective leadership should not only be seen from how far the leaders' organizational unit succeeds in accomplishing the task of achieving their goals. Equally important is the process of leadership itself which then affects the employees' perception on the leadership styles of their leaders. Employees perceive their leaders' behavior, mainly based on two categories (i.e., related to the purpose of the tasks and related to interpersonal relationships). Employees are most satisfied when they perceive their direct leaders run both behaviors (Madlock, 2008).

Judged from the leadership styles, female leaders run their task-oriented leadership without ignoring good relationship with their employees, as the conclusion which can be drawn from the article of Psychological Bulletin Vol. 129 No. 3 reviewed in Sinar Harapan Daily, on the advantages of female leaders. Numerous studies show that men and women respond to aspects of social relations differently (Eagly, 2007; Koenig, Eagly, Mitchell, \& Ristikari, 2011). Compared to men, women are more prominent in 
the communal dimension, which is personal-oriented relationships and cares for the well-being of others (Eagly, 2009; Girdauskiene \& Eyvazzade, 2015). Nevertheless, Eagly's study showed no gender differences in terms of orientation dimensions in the assignment and assertive behavior such as ambitious, dominating, and competitive (Eagly, Johannesen-Schmidt, \& van Engen, 2003) on men and women in leadership roles. However, the fact shows that there is still a lot of differentiating positions for different genders. Women often gain a lower position than male counterparts do, and they do not get equal opportunities in career development (Hastuti, 2005).

Although more than half of Indonesia's population is women, their underdevelopment conditions may illustrate injustice and inequalities between men and women (Soemartoyo, 2002). In organizational scope, the opportunity for female employees to occupy managerial positions or to become a structural leader in an organizational unit is relatively lower than male employees do, despite the technical skills required. Surely, the things which will be studied in this study are more on the organizational subjective and objective obstacles, regardless of cultural and social problems.

\section{Literature Review \\ Leadership Style}

Most researchers evaluate the effectiveness of leadership based on the consequences of leaders' actions for their followers and other components within the organization. The most widely used measurement is how far the organizational unit of leaders succeeds in accomplishing tasks of achieving its goals, both objectively and subjectively. The selection of appropriate criteria also depends on the purpose and the values made by the person conducting the evaluation, while everyone has different values (Yukl, 2009). Michigan Leadership Study proposed effective leadership behaviors which was different from those previous studies. Employees view their supervisors' behavior mainly based on two categories, one of which related to task purposes and the other related to interpersonal relationships.

\section{Task-oriented behavior}

Effective managers use their time and efforts to concentrate on task or job-oriented functions different from their employees, such as planning and coordinating their employees' activities, helping their employees to set high but realistic performance goals.

2. Relationship-oriented behavior

For effective managers, task-oriented behavior does not mean sacrificing attention to human relationships. The leaders' behaviors supporting this idea, among others are, showing trust and credibility, acting friendly and caring, seeking to understand the employees' issues, showing appreciation of the employees' ideas, and giving recognition to their contributions and achievements.

In large organizations, the effectiveness of managers depends on the strength of their influence on the leaders and colleagues and their employees. That means, influencing is the essence of leadership. Various leadership functions can be run by different people who give influence on what groups do, how to do it, and how group members relate to one another. This interactive process, of course, involves many people influencing each other. The problem is not just who uses the influence, but also the kind of influence used and what the outcomes are. There are conflicting points of view, in which the definition of leadership is limited using influence resulting in high commitment from employees regardless of discontent or unwillingness to obey the leadership. Another contradictory view is that one who uses control over rewards and punishments for manipulating or forcing followers is not really "leading" them and unethical because it is an abuse of power. Thus, the first view can eliminate some of the influencing processes which are important to understand why a manager is effective or not in certain situations. The same kind of influence can give different results depending on the nature of the situation, and the same leadership outcomes can be achieved by different influencing methods.

\section{Communication}

Good communication in organization has a variety of important roles. First, communication is the key to efforts to coordinate activities within the organization. Second, communication plays a role to share information in putting forward facts, data, instructions, direction between units within the organization. Third, communication is essential for developing friendships and building trust and acceptance of the message receivers. In this case, their role deals with building social relationships within the organization. 
What people say and how to say it can have an impact on others. Therefore, in order to create a pleasant interpersonal atmosphere in the workplace, the organization members should pay attention to the communication factors. Eventually, the role which is much more important, especially for a leader as a communicator, is the role of communication in decision-making.

Every individual has differences in his/her communication styles, which is not only influenced by his/her personal communication styles, but also by gender and cross-cultural differences. It is important to understand that all these styles can be learned and applied. Each style has its strengths and weaknesses, there is no single style that works best among others. Generally, individuals tend to use one style. Effective communication begins by recognizing one-self's communication style and then that of others. Therefore, when someone meets and interacts with others, it is better to try to understand and then, as much as possible, to adjust the other person's style.

Men and women, one another, are often misconstrued because they use different ways of communicating. It is the difference that makes them address the problem differently. Men tend to be good speakers, emphasizing and strengthening their status when speaking, unlike women do. While women focus on creating positive social relationships, tending to listen to others, and being more emotional. It would be wise for a manager or leader to appreciate and accept the differences. Getting a better understanding that everyone has a different way of speaking in terms of putting forward meanings, it is more likely to gain benefits from a variety of potential employees with different communication styles. namely:

Communication within groups or organizations has 4 main functions (Halim \& Razak, 2014),

Control: Through communication, a leader can determine whether an employee is doing the job according to the organizations' needs, or whether a problem related to his job occurs.

Motivation: Communication becomes a motivation through an explanation of what role an employee should play, what achievement they have done so far, and what can be done to improve it.

Emotional expression: For some employees, work-group is a major source of social interaction. Communication provides a freedom to express feelings and fulfillment of social needs.

Information: Each member of an organization needs information to make decision by identifying and evaluating alternative options. With the competitive pressures faced by the organization today, strategy formulation, decision making, motivation, team building, and negotiation then require a leader's abilities to communicate effectively.

\section{Communication skills}

Communication is defined as a process by which a sender conveys various types of information to a receiver. Everyone can be a communicator or run a communication process. However, the quality of communication can vary depending on how good a communicator is able to communicate effectively. Not only is delivered, accepted, understood by the recipient of the message, but also effectively achieving the communication purposes, punctual and situational, and on target.

Individuals who are competent in communication are not only seen from how far the message communicated reaches its goal, but not less important is, how it is done properly. From the internal side of the individual concerned, his/her communication skills are constructs including the elements of knowledge, motivation, skills, behavior, and effectiveness (Berman \& Hellweg, 1989). Communicative individuals have abilities to use communicative resources (such as gestures, language, and voice) effectively in achieving social goals (Stohl, 1985). Then Larson, Backlund, Redmond, and Barbour (1978) stated that communication skill is an individual ability to demonstrate knowledge about appropriate communication behavior in certain situations. This statement is reaffirmed by McCroskey (1982), saying that the point is the proper communicative behavior, whereas from the subject side, competent communicators are those who are effective in achieving their goals or maximizing the goals' accomplishment through communication.

\section{Motivating language}

Motivating Language Theory (ML) predicts that intentional use in the way a leader speaks can significantly improve employees' attitudes and several outcomes such as job satisfaction, performance, and innovation (Mayfield \& Mayfield, 2006). Initially, this theory was conceptualized by Sullivan (1988) 
to encourage employees' motivation which then formed the employees' speaking behavior which encouraged the organizational goals. According to Sullivan, there are 3 types of speech, namely:

Direction-giving language occurs when the leader explains goals to his/her employees and alleviates organizational uncertainty. For example, a manager uses this type when helping employees prioritize the interests of each project in various assignments.

Empathetic language used when the leader speaks with a compassionate understanding to his/her employees. The manager uses this empathetic language when he/she offers enthusiasm or encouragement.

Meaning-making language, occurs when the leader conveys the rules of an organizational culture to their employees. For example, a manager uses this way of speaking when he/she gives political advice to his/her employees to produce a corporate buy-in on a project. Cooke and Rousseau (1988) observed that the meaning-making language is often delivered indirectly in the form of a story or organization's history.

\section{Barriers to female leadership}

Obstacles to Female leadership are related to 2 (two) things, namely:

Objective conditions or institutionalized mistreatment on women. For example, getting a lower salary than men do, not getting a chance on a work or organization, and a contract bond for not getting married for a certain time.

Subjective conditions or stereotyped assumptions about women. For example, the assumption that woman is weaker than man, skilled in the kitchen but bad drivers, or the assumption that women are soft, warm, but lacking power, slow, and unintelligent. Objective conditions appear to be supported by discriminative laws, practices and traditions on female workers. If this happens, then this becomes an external obstacle in women's leadership. Women are not given the opportunity to perform certain tasks, nor encouraged to achieve higher positions/levels (job promotion), and - compared to men- relatively and rarely get training opportunities which support their career development.

In contrast to the objective conditions above, subjective conditions are the attitudes of others towards women based on misinformation about women, and acceptance of the inequality of opportunity for women as stated earlier. This condition is an internal barrier in women's leadership. Both internal and external barriers must be eliminated. One constraint cannot be eliminated without eliminating other barriers, it must be done simultaneously.

\section{Research Hypotheses}

Leadership in an organization requires a leader figure who can direct, motivating, mobilizing human resources, and communicating his/her visions effectively so that his/her employees will experience high levels of satisfaction. As Pavitt remarked, when leaders effectively communicate their visions, they are more likely to gain their employees' trust, which eventually affect communicating satisfaction between leaders and their followers (Madlock, 2008). Communication skills lead to individuals' abilities to demonstrate their competence, which is not only to communicate the message verbally, but also abilities to listen to other people's messages and to negotiate. In order to persuade employees to follow their visions, leaders need to communicate effectively by involving the followers' the interests. A Study conducted by Berman and Hellweg (1989) found out that leaders' communication skills perceived by their employees related to the employees' satisfaction with their bosses.

Previous studies have shown that interpersonal interactions involving information exchange and affected among colleagues and between employees and their managers directly result in significant impacts on working attitudes, such as job satisfaction, organizational commitment and burnout (Pincus, 1986; Postmes, Tanis, \& de Wit, 2001; Ray \& Miller, 1994). Therefore, the hypotheses can be formulated as follows:

H1a: Leaders' communication skills had a positive effect on employees' communication satisfaction

H1b: Leaders' communication skills had a positive effect on employees' job satisfaction.

The effectiveness of communication is broadly associated with leadership effectiveness (Klauss \& Bass, 1982), and this is reflected in several measurements of leadership behavior and communication 
styles in leadership literatures. Likewise, Locke and his colleagues (1991) argued that effective personal communication skills enable leaders to create and disseminate their visions to followers.

The conceptualization of communicating satisfaction is presented by Crino and White (1981), who argued that organizational communicating satisfaction includes individual satisfaction regarding various aspects of communication within an organization, as quoted by Putti, Aryee, and Phua (1990) in their study, indicating that the communicating satisfaction of organization members is related with the amount of information available to them. Effective communication between leaders and followers can create a positive impression and increase perceptions about the leaders' performance (Conger \& Kanungo, 1998; Gardner \& Martinko, 1988; Rao, et al. 1995). Anderson and Martin (1995) found that employees interact in communication with colleagues and managers satisfy interpersonal needs. Thus, the following hypotheses can be formulated:

H2a: Task-oriented leadership style had a positive effect on employees' communicating satisfaction.

H2b: Task-oriented leadership style had a positive effect on employees' job satisfaction.

H3a: Relationship-oriented leadership style had a positive effect on employees' communicating satisfaction.

H3b: Relationship-oriented leadership style had a positive effect on employees' job satisfaction.

As Stanford's statement, Oates and Flores (1995) characterized female leaders as someone who has a high level of involvement with employees. Women run effective communication based on mutual respect and trust with their employees, motivating, and inspiring. Compared to men, women have higher interpersonal skills. This is driven by women's belief that people will perform best when they feel themselves and work well, and try to create situations which reinforce those feelings (Alimo-Metcalfe, 2010). Similarly, Evans (2014) argued that women tend to be more effective in terms of interpersonal skills, empathy, emotion and relationship handling. Such female characters support their abilities to communicate different approaches to men.

\section{Research Methods \\ Sample and Data Collection}

The population of the study was all employees at private Islamic universities in Semarang city, Indonesia. The samples were selected using purposive sampling technique. Based on the criteria and by considering the need of the fulfillment of respondents with male and female leaders, the number of samples was 200 respondents. Data further were collected using structured questionaires.

\section{Measurement}

Communication skills were measured using 12 items which adopted from Communicator Competence Questionnaire (Berman \& Hellweg, 1989). All items were measured using a 5-point Likert scales where $1=$ strongly disagree and $5=$ strongly agree. Job satisfaction was measured using 20 items which adopted from Minnesota Satisfaction Questionnaire (MSQ) (Weiss, Dawis, England, \& Lofquist, 1967). Communication ssatisfaction was measured using 19 items which adopted from Interpersonal Communication Satisfaction Inventory (ICSI) (Hecht, 1978). Leadership Styles were measured using 20 items which adopted from Leadership Style Questionnaire (Northouse, 2001).

\section{Result and Discussion}

The questionnaires given in the scene were 275 pieces for the respondents. Out of these, not all questionnaires could be used to analyze. Among the returned questionnaires, only 200 questionnaires could further be processed.

\section{Validity and reliability test results}

Validity refers to the extent to which a test can measure what we really wanted to measure. The test in this study was done by using factor analysis, which aimed to ensure that each question item was classified in predetermined variables. Table 1 showed that all question items used in this study were valid, because the loading factor was greater than 0.4 . 
Table 1. Summary of Validity Test Results

\begin{tabular}{|c|c|c|c|c|c|}
\hline & $\begin{array}{l}\text { Communication } \\
\text { Skills }\end{array}$ & $\begin{array}{l}\text { Job } \\
\text { Satisfaction }\end{array}$ & $\begin{array}{l}\text { Communicating } \\
\text { Satisfaction }\end{array}$ & $\begin{array}{l}\text { Task-Oriented } \\
\text { Leadership Style }\end{array}$ & $\begin{array}{l}\text { Relationship- } \\
\text { Oriented } \\
\text { Leadership Style }\end{array}$ \\
\hline CK1 &, 560 & & & & \\
\hline CK2 & 606 & & & & \\
\hline CK3 & 658 & & & & \\
\hline CK4 & ,533 & & & & \\
\hline CK5 &, 526 & & & & \\
\hline CK6 & ,495 & & & & \\
\hline CK7 & 601 & & & & \\
\hline CK8 & 653 & & & & \\
\hline CK9 & 676 & & & & \\
\hline CK10 & ,532 & & & & \\
\hline CK11 & 764 & & & & \\
\hline CK12 & 765 & & & & \\
\hline KJ1 & & ,813 & & & \\
\hline $\mathrm{KJ} 2$ & & ,835 & & & \\
\hline $\mathrm{KJ} 3$ & & ,802 & & & \\
\hline KJ4 & & 652 & & & \\
\hline KJ5 & & 684 & & & \\
\hline KJ6 & & 677 & & & \\
\hline KJ7 & & ,499 & & & \\
\hline KJ8 & & 653 & & & \\
\hline KJ9 & & 610 & & & \\
\hline KJ10 & & 634 & & & \\
\hline KJ11 & & 656 & & & \\
\hline KJ12 & & 749 & & & \\
\hline KJ13 & & ,762 & & & \\
\hline KJ14 & & ,842 & & & \\
\hline KJ15 & & ,852 & & & \\
\hline KJ16 & & ,852 & & & \\
\hline KJ17 & & 690 & & & \\
\hline KJ18 & & ,593 & & & \\
\hline KJ19 & & 712 & & & \\
\hline KJ20 & & 615 & & & \\
\hline PK1 & & & 757 & & \\
\hline PK2 & & & ,573 & & \\
\hline PK3 & & & 628 & & \\
\hline PK4 & & & 775 & & \\
\hline PK5 & & & ,596 & & \\
\hline PK6 & & & ,884 & & \\
\hline PK7 & & & 747 & & \\
\hline PK8 & & & 821 & & \\
\hline PK9 & & & 685 & & \\
\hline PK10 & & & 733 & & \\
\hline PK11 & & & 796 & & \\
\hline PK12 & & & 769 & & \\
\hline PK13 & & & 778 & & \\
\hline PK14 & & & ,822 & & \\
\hline PK15 & & & 795 & & \\
\hline PK16 & & & 799 & & \\
\hline PK17 & & & ,805 & & \\
\hline PK18 & & & 632 & & \\
\hline PK19 & & & 700 & & \\
\hline GKT1 & & & & 603, & \\
\hline GKT2 & & & & 617, & \\
\hline GKT3 & & & & ,578 & \\
\hline
\end{tabular}




\begin{tabular}{lrr}
\hline GKT4 &, 672 & \\
GKT5 &, 556 & \\
GKT6 &, 763 &, 734 \\
GKT7 &, 693 &, 591 \\
GKT8 & &, 742 \\
GKH1 &, 485 \\
GKH2 &, 711 \\
GKH3 &, 526 \\
GKH4 &, 620 \\
GKH5 &, 671 \\
GKH6 &, 497 \\
GKH7 &, 697 \\
GKH8 & \\
GKH9 & \\
GKH10 &, 512 \\
GKH11 & \\
GKH12 &, 599 \\
\hline
\end{tabular}

This study used Cronbach's Alpha method to measure the reliability. Score values between 0.8 - 1 were categorized as good reliability, alpha values 0.6 - 0.79 were categorized as acceptable reliability, and alpha values less than 0.6 were categorized as poor (Sekaran, 1992).

Table 2. Summary of Validity Test Results

\begin{tabular}{lll}
\hline Variables & Cronbach's Alpha & Category \\
\hline Communication Skills & 0,877 & Good \\
Job satisfaction & 0,699 & Acceptable \\
Communicating Satisfaction & 0,883 & Good \\
Task-Oriented Leadership Style & 0,866 & Good \\
Relationship-Oriented Leadership & 0,941 & Good \\
Style & & \\
\hline
\end{tabular}

In this study, the hypotheses testing was done by using simple regression test and independent samples $\mathrm{T}$ test. Simple regression analysis was done to test the hypotheses proposed, while independent samples $\mathrm{T}$ test was conducted to examine differences in communication skills and leadership styles of male and female leaders, based on employees' perceptions. A summary of the overall findings of the analysis can be read from Table 3 to Table 4 .

Table 3. Summary of hypotheses testing results

\begin{tabular}{|c|c|c|c|c|c|}
\hline Variables & Beta & Sig. & Adj R ${ }^{2}$ & $\mathrm{~F}$ & Results \\
\hline $\mathrm{CK} \rightarrow \mathrm{PK}$ & 0,766 & $0,000^{*}$ & 0,584 & $280,546^{*}$ & Supported \\
\hline $\mathrm{CK} \rightarrow \mathrm{KJ}$ & 0,570 & $0,000^{*}$ & 0,321 & $95,245^{*}$ & Supported \\
\hline $\mathrm{GKT} \rightarrow \mathrm{PK}$ & 0,632 & $0,000^{*}$ & 0,396 & $131,397^{*}$ & Supported \\
\hline $\mathrm{GKT} \rightarrow \mathrm{KJ}$ & 0,376 & $0,000^{*}$ & 0,137 & $32,521^{*}$ & Supported \\
\hline $\mathrm{GKH} \rightarrow \mathrm{PK}$ & 0,801 & $0,000^{*}$ & 0,639 & $353,888^{*}$ & Supported \\
\hline $\mathrm{GKH} \rightarrow \mathrm{KJ}$ & 0,594 & $0,000^{*}$ & 0,349 & $107,696^{*}$ & Supported \\
\hline
\end{tabular}

Note: $C K=$ Communication Skills, $P K=$ Communicating Satisfaction, $K J=$ Job Satisfaction, GKT= Task-Oriented Leadership Style, GKH= Relationship-Oriented Leadership Style

* Significant on $p<0.05$

Table 4. The Result of Regression Analysis

\begin{tabular}{llll}
\hline Variables & Beta & Sig. & Mean Difference \\
\hline CK $\rightarrow$ sex & $-0,091$ & 0,927 & $-0,00679$ \\
GK $\rightarrow$ sex & $-0,820$ & 0,413 & $-0,05379$ \\
\hline
\end{tabular}

Note: sex: Leaders' gender being assessed

* Significant on $p<0.05$

Hypothesis 1a testing using regression analysis showed that the leaders' communication ability had a positive and significant effect on the employees' communicating satisfaction $(b=0.766 ; p=0,000)$. Therefore, it is proven that the hypothesis was supported. It could be understood if the communication 
skills affected the employees' satisfaction on the communication with the direct leaders. It is because leaders cannot be separated from their roles as communicators. Submission of instructions, information, duties and responsibilities of employees absolutely covers clarity on all of things which did not only benefit the organization, but also the employees. So, when a leader can be an effective information conveyor, a good listener, and sensitive to the needs and aspiration of the bottom, the employees who are under his/her command will be more satisfied with the communication needs.

From the results of hypothesis testing, it is proved that the leaders' communication skills had a positive and significant impact on the employees' job satisfaction $(b=0,570 ; p=0,000)$. The communication skills were significantly able to explain $32.1 \%$ variation in job satisfaction variables (Adj $\mathrm{R} 2=0.321 ; \mathrm{F}=95.245 ; \mathrm{p}=0,000)$. The competence of the leaders' communication determined how much they can direct and giving encouragement in achieving organization goals. All of them were run through directing and controlling mechanisms which were undoubtedly supported by the leaders' communication skills concerned as it has been known that a leader as manager is a representation of a organization. So, how effective managers perform the integration function will determine the perception of their employees about the amount of organizational supports that affect their job satisfaction.

Hypothesis 2a stated that the managers' leadership style which was task-oriented positively influenced the employees' communicating satisfaction. The test results with regression analysis showed that the coefficient of determination was 0.396 . This means that $39.6 \%$ of variation in communicating satisfaction variables could be explained by the task leadership style, and their effect on communicating satisfaction was significant $(b=0.632 ; p=0,000)$. The support of this hypothesis further reinforced the findings of the previous studies, as described in the bibliography reviews in the previous chapter.

From the testing result on hypothesis $2 \mathrm{~b}$ using regression analysis, it can be concluded that the task-oriented leadership style had a direct and significant effect on the employees' job satisfaction $(b=$ 0.376; $p=0,000$ ), and the leadership style could explain 13,7\% variation in the dependent variable (Adj R2 $=0,137 ; \mathrm{F}=32,521 ; \mathrm{p}=0,000)$. The support of this hypothesis reinforced Anderson and Martin's (1995) findings, pointing out that the clarity of job duties would contribute to the employees' satisfaction. The clear set and communicated performance standards, the clarity of each employee's responsibility, and the encouragement of qualified job as the characteristics of task-oriented leadership style significantly determined the employees' job satisfaction.

The result of hypothesis 3 a testing with regression analysis showed that the relationship-oriented leadership style explained the variation of employees' communicating satisfaction equal to 63,9\% (Adj R2 $=0,639 ; \mathrm{F}=353,888 ; \mathrm{p}=0,000)$ and proved to have significant positive effect $(\mathrm{b}=0,801 ; \mathrm{p}=0,000)$. The support of this hypothesis reinforced the findings of the previous studies (Anderson \& Martin, 1995), stating that the interaction of employees' communication with leaders who satisfied their interpersonal needs would contribute to the employees' communicating satisfaction.

The result of hypothesis $3 \mathrm{~b}$ testing showed that relationship-oriented leadership style explained significantly variation in the job satisfaction variable (Adj R2 $=0,349 ; \mathrm{F}=107,696 ; \mathrm{p}=0,000$ ). It had positive and significant influence on the dependent variable $(b=0,594 ; p=0,000)$. This was acceptable, considering the leaders' friendly attitudes, fair behavior, personal attention, supporting the employees' efforts, both individually and in teams, was not only important in the job execution, but also caused pleasure in working. It was not surprising that such leadership style could effectively improve the employees' job satisfaction.

The result of hypothesis 4 and 5 testing as shown in Table 4 showed that there was no difference in communication skills in male and female leaders. Similarly, male-to-female leadership styles showed no significant differences, based on their employees' assessment. This was the evident from the test results where the significance was 0.927 and 0.413 . Moreover, the mean difference between male and female leaders was very small, less than 0.1 (mean difference $=-0.00679$ and -0.05379 ). The unsupported hypotheses 4 and 5 related to the subjects in this study who were the employees in private companies. Policies in human resource management in private companies were clearly different from governmental companies. Related to policy on promotional positions, determination of compensation, bureaucracy, formalities of interaction between leaders and employees, were very different. Performance base became the basis of policy determination for private companies, unlike governmental companies which tend to be 
formal, rigid, and seniority prioritization. This made the employees, who occupied the leader position in private companies, had been considered in terms of their competence including the ability to communicate and leadership, regardless of whether the person was male or female. As Appelbaum, Audet and Miller's (2003) research findings, stating that men could learn about women's leadership styles and applied them effectively. In other words, an effective leadership style was not a specific exclusive gender domain, and both could learn from each other.

\section{Conclusion}

Either communication skills or task and relationship-oriented leadership styles play an important role in determining employees' working attitudes, especially their satisfaction with the growing communication relationships with their direct leaders and their satisfaction with the work they are doing. Interestingly, refer to male and female leaders, this study found there is no significant difference in communication skills and leadership styles.

Further studies related to communication and leadership need to explore and examine more deeply with different settings. In order to assess the differences in communication and leadership capabilities between male and female, the next studies should not be limited to private universities, but it more expanded to other types of organizations. In addition, direct interviews with organization management can also support a descriptive explanation on existing quantitative analysis.

\section{References}

Alimo-Metcalfe, B. (2010), An investigation of female and male constructs of leadership and empowerment, pp. 640648.

Anderson, C. M., \& Martin, M. M. (1995). The effects of communication motives, interaction involvement, and loneliness on satisfaction: A model of small groups. Small Group Research, 26, 118-137.

Appelbaum, S. H., Audet, L., \& Miller, J. C. (2003),"Gender and leadership? Leadership and gender? A journey through the landscape of theories", Leadership \& Organization Development Journal, Vol. 24 Iss 1 pp. 43 - 51

Berman, S. J., \& Hellweg, S. A. (1989). Perceived supervisor communication competence and supervisor satisfaction as a function of quality circle participation. The Journal of Business Communication, 26 (2): 103-122.

Conger, \& Kanungo (1998). Charismatic leadership in organizations. Sage, Thousand Oaks, CA

Crino, M. E., \& White, M. C. (1981). Satisfaction in communication: An examination of the Downs-Hazen measure. Psychological Reports, 49, 831-838.

Eagly, A. H. (2007). Female leadership advantage and disadvantage: Resolving the contradictions. Psychology of women quarterly, 31(1), 1-12.

Eagly, A. H. (2009). The his and hers of prosocial behavior: an examination of the social psychology of gender. American Psychologist, 64(8), 644.

Eagly, A. H., Johannesen-Schmidt, M. C., \& van Engen, M. L. (2003). Transformational, transactional, and laissez-faire leadership styles. Psychological Bulletin, 129(4), 569-591.

Evans, D. P. (2014). Aspiring to Leadership... A Woman's World?. Procedia-Social and Behavioral Sciences, 148, 543-550.

Gardner, W. L., \& Martinko, M. J. (1988). Impression management in organizations. Journal of management, 14(2), 321338.

Girdauskiene, L., \& Eyvazzade, F. (2015). The profile of an effective female leadership in multicultural context. Procedia-Social and Behavioral Sciences, 210, 11-20.

Halim, N. A. A., \& Razak, N. A. (2014). Communication Strategies of Women Leaders in Entrepreneurship. ProcediaSocial and Behavioral Sciences, 118, 21-28.

Hall, R. J., \& Lord, R. G. (1995). Multi-level information-processing explanations of followers' leadership perceptions. The Leadership Quarterly, 6, 265-281.

Hastuti, E. L. (2005). Hambatan sosial budaya dalam pengarusutamaan gender di Indonesia. Working Paper. Pusat Penelitian dan Pengembangan Sosial Ekonomi Pertanian.

Hecht, M. L. (1978). The conceptualization and measurement of interpersonal communication satisfaction. Human Communication Research, 4, 253-264.

Holladay, S. J., \& Coombs, W. T. (1993). Communication visions: An exploration of the role of delivery in the creation of leader charisma. Management Communication Quarterly, 6, 405-427.

Koenig, A. M., Eagly, A. H., Mitchell, A. A., \& Ristikari, T. (2011). Are leader stereotypes masculine? A meta-analysis of three research paradigms. American Psychological Association, 137 (4), 616-642.

Larson, C. E., Backlund, P. M., Redmond, M. K., \& Barbour, A. (1978). Assessing communicative competence. Falls Church, VA: Speech Communication Association and ERIC. 
Locke, Kirkpatrick, Wheeler, Schneider, Niles, Goldstein, Welsh, \& Chah. (1991). The essence of leadership. Lexington Books, New York

Madlock, P. E. (2008). The link between leadership style, communicator competence, and employee satisfaction. Journal of Business Communication, 45 (1): 61-78.

Mayfield, J., \& Mayfield, M. (2006). The benefits of leader communication on part-time worker outcomes: A comparison between part-time and full-time employees using motivating language. Journal of Business Strategies, 23 (2): 131-153.

McCroskey, J. C. (1982). Communication competence and performance: A research and pedagogical perspective. Communication Education, 31,1-7.

Northouse, P. G. (2001). Leadership: Theory and practice (2nd ed.). Thousand Oaks, CA: Sage.

Pincus, D. (1986). The impact of organizational communication on job satisfaction and job performance. Paper disampaikan pada The International Communication Association Convention, Honolulu, HI.

Postmes, T., Tanis, M.,\& de Wit, B. (2001). Communication and commitment in organizations: A social identity approach. Group Processes E Intergroup Relations, 4, 227-246.

Putti, J. M., Aryee, S., \& Phua, J. (1990). Communication relationship satisfaction and organizational commitment. Group E Organization Studies, 15, 44-52.

Rao, A, Schmidt SM, Murray LH (1995) Upward impression management: goals, influence strategies, and consequences. Human Relations, 48 (2): 147-167.

Ray, E. B., \& Miller, K. I. (1994). Social support: Home/work stress and burnout: Who can help? Journal of Applied Behavioral Science, 30, 357-373.

Sullivan, J. J. (1988). Three roles of language in motivation theory. Academy of Management Review, 13(1), $104-115$.

Sekaran, U. (1992). Research Methods for Business: A Skill-Building Approach. Second Edition. John Wiley \& Sons, Inc. Singapore.

Shaw, K. (2005). Getting leaders involved in communication strategy: Breaking down the barriers to effective leadership communication. Strategic Communication Management, 9,14-17.

Soemartoyo. (2002). Pemberdayaan Perempuan di Indonesia dan Peluang Untuk Pemberdayaan Ekonomi Perempuan. Disampaikan oleh Menteri Pemberdayaan Perempuan pada The ACT Seminar and Summit. Japan-Indonesia: Dinamic Relationship for Regional Development.

Stanford, J. H., Oates, B. R., \& Flores, D. (1995). Women' s leadership styles: a heuristic analysis. Women in Management Review, 10(2), 9-16.

Stohl, C. (1984). Quality circles and the quality of communication. Paper disampaikan pada The Speech Communication Association Convention, Chicago, IL.

Weiss, D. J., Dawis, R. V., England, G. W., \& Lofquist, L. H. (1967). Manual for the Minnesota satisfaction questionnaire. Minneapolis. Minn.: University of Minnesota Industrial Relations Center.

Yukl, G. (2009). Leadership in Organizations. Prentice Hall, $7^{\text {th }}$ edition. 